\title{
Neurobiological Basis of Increased Risk for Suicidal Behaviour
}

\author{
Aleksandra Wisłowska-Stanek ${ }^{1, *}$, Karolina Kołosowska ${ }^{2}$ and Piotr Maciejak ${ }^{1,2}$ \\ 1 Centre for Preclinical Research and Technology (CEPT), Department of Experimental and Clinical Pharmacology, \\ Medical University of Warsaw, 1B Banacha Street, 02-097 Warsaw, Poland; pmaciejak@ipin.edu.pl \\ 2 Department of Neurochemistry, Institute of Psychiatry and Neurology, 9 Sobieskiego Street, \\ 02-957 Warsaw, Poland; kkolosowska@ipin.edu.pl \\ * Correspondence: awislowska@wum.edu.pl; Tel.: +48-221166160
}

check for

updates

Citation: Wisłowska-Stanek, A.;

Kołosowska, K.; Maciejak, P.

Neurobiological Basis of Increased

Risk for Suicidal Behaviour. Cells

2021, 10, 2519. https://doi.org/

10.3390/cells10102519

Academic Editors: Marta

Dziedzicka-Wasylewska and Agata

Faron-Górecka

Received: 31 August 2021

Accepted: 21 September 2021

Published: 23 September 2021

Publisher's Note: MDPI stays neutral with regard to jurisdictional claims in published maps and institutional affiliations.

Copyright: (C) 2021 by the authors. Licensee MDPI, Basel, Switzerland. This article is an open access article distributed under the terms and conditions of the Creative Commons Attribution (CC BY) license (https:// creativecommons.org/licenses/by/ $4.0 /)$.

\begin{abstract}
According to the World Health Organization (WHO), more than 700,000 people die per year due to suicide. Suicide risk factors include a previous suicide attempt and psychiatric disorders. The highest mortality rate in suicide worldwide is due to depression. Current evidence suggests that suicide etiopathogenesis is associated with neuroinflammation that activates the kynurenine pathway and causes subsequent serotonin depletion and stimulation of glutamate neurotransmission. These changes are accompanied by decreased BDNF (brain-derived neurotrophic factor) levels in the brain, which is often linked to impaired neuroplasticity and cognitive deficits. Most suicidal patients have a hyperactive hypothalamus-pituitary-adrenal (HPA) axis. Epigenetic mechanisms control the above-mentioned neurobiological changes associated with suicidal behaviour. Suicide risk could be attenuated by appropriate psychological treatment, electroconvulsive treatment, and drugs: lithium, ketamine, esketamine, clozapine. In this review, we present the etiopathogenesis of suicide behaviour and explore the mechanisms of action of anti-suicidal treatments, pinpointing similarities among them.
\end{abstract}

Keywords: suicide; serotonin; kynurenine pathway; cortisol; BDNF; epigenetics; lithium; ketamine; esketamine; clozapine

\section{The Scope of the Problem}

According to the World Health Organization (WHO), more than 700,000 people die each year due to suicide, while suicide attempts are 10-20 times more frequent [1]. Suicide accounts for $8.5 \%$ of deaths among adolescents and young adults (15-29 years) and is the second leading cause of death among this population worldwide. Completed suicides are three times more common in males than females, while for suicide attempts, an inverse ratio is observed [2]. Suicide risk factors include a previous suicide attempt, non-suicidal self-harm, and psychiatric disorders [3-5]. It is estimated that $90 \%$ of suicide victims have at least one mental disorder $[3,4,6]$. Over $50 \%$ of suicides occur in patients with major depression or bipolar disorders, especially when they are treatment resistant $[3,7,8]$. On the one hand, thirty percent of patients with treatment-resistant depression attempt suicide at least once during their life [9]. The second cause of suicide is alcohol abuse [10]. Other risk factors are schizophrenia, post-traumatic stress disorder (PTSD), anorexia nervosa, sleep disorder, antisocial personality disorder, borderline personality disorder, and/or substance abuse $[3,7,11,12]$. On the other hand, only $5 \%$ of psychiatric patients commit suicide. This particular risk group includes patients requiring hospital treatment (10 times higher than in the general population) [13]. In addition to psychiatric conditions, suicidal behaviour has been associated with chronic diseases, especially those with unfavourable prognoses or accompanying chronic pain such as HIV infection or cancer $[2,14,15]$.

Traits that increase the probability of suicidal behaviour include aggression, impulsivity, pessimism, hopelessness, impaired cognitive functions, and poor affect regulation $[3,16,17]$. Higher levels of impulsivity and aggression are especially seen in younger suicide victims [18]. 
Suicidal behaviour is thought to be triggered by an interplay between genetic, psychological, and environmental factors [19]. The estimated heritability of suicidal behaviour has been shown to range from 30 to $55 \%$ in twin studies $[19,20]$. Several studies have suggested that the likelihood of attempting or committing suicide is ten times higher in relatives of suicide completers. Genome-wide association studies (GWAS) have indicated that polygenic risk and specific loci such as genes involved in circadian clock regulation, tyrosine metabolism, and risk factors for depressive disorder are associated with a higher risk of attempting suicide [20,21]. The stress-diathesis model assumes that stressors interact with neurobiological and psychological susceptibilities to cause suicidal behaviour as the maladaptive stress response [22-26]. A chronic and acute stressful situation such as deprivation, isolation, family adversity, sexual abuse, school, employment and financial difficulties, and experiences of loss and death can increase the incidence of suicidal behaviour $[27,28]$. Data suggest that early life adversity is especially harmful and increases the rate of impulsive and suicidal behaviour by two to five times $[6,29,30]$. Table 1 summarises the risk factors and factors associated with a decreased risk of suicide.

Table 1. Risk factors of suicide and matching treatment that decreases the risk of suicide.

\begin{tabular}{cc}
\hline Risk Factors of Suicide & Matching Treatment That Decreases the Risk of Suicide \\
\hline Emotional traits: aggression, impulsivity, pessimism & $\begin{array}{c}\text { Lithium (in depression and bipolar disorder, delayed effect), } \\
\text { clozapine (schizophrenia) }\end{array}$ \\
\hline Early life stress & $\begin{array}{c}\text { Ketamine/esketamine (in depression, rapid effect), lithium (in } \\
\text { depression and bipolar disorder, delayed effect), electroconvulsive } \\
\text { therapy, psychotherapy, transcranial magnetic stimulation }\end{array}$ \\
\hline Schizophrenia & Clozapine \\
\hline Other psychiatric disorders & Psychotherapy \\
\hline Alcohol dependence and other dependence & Treatment of alcohol or substance abuse
\end{tabular}

\section{The Biological Background of Suicidal Behaviour}

Many psychological tools can be useful to evaluate the risk of suicidal behaviour, such as the Suicide Intent Scale, the Suicide Assessment Scale, the Karolinska Interpersonal Violence Scale, the Columbia Suicide Severity Rating Scale, the Beck Hopelessness Scale, and the Harcavy-Asnis Suicide Scale [15,31,32]. Some scales help to validate the risk of suicide in children and/or adolescents, such as the Child Suicide Potential Scale, the Evaluation of Suicide Risk Among Adolescents, and Imminent Danger Assessment [33,34]. All these scales are based on asking individuals about suicidal intentions and risk factors of suicide. However, in many cases, suicide scales provide insufficient predictive validity for future suicide attempts. They are limited by a patient's willingness to share information, as well as a high rate of false positives. To date, the best method to assess a patient's risk for suicide is screening for past suicide attempts. Hence, searching for potential biological markers could be very beneficial, especially in situations associated with an increased risk of suicide, including a severe episode of depression, psychosis, or hospitalisation.

Suicide etiopathogenesis seems to be associated with neuroinflammation that stimulates the kynurenine pathway and causes the depletion of serotonin and melatonin [31]. A decreased level of serotonin is associated with aggression and impulsivity [35]. Proinflammatory cytokines activate the hypothalamic-pituitary-adrenal axis [36]. Moreover, increased metabolism of kynurenic acid into neurotoxic quinolinic acid, an NMDA receptor agonist, results in glutamatergic system overactivation and a decrease in the production of $\mathrm{BDNF}$, which worsens neuroplasticity and could cause cognitive problems [37].

The Niculescu group suggested the following potential markers of suicidality: interleukin6 (IL-6), MAO-B (monoamine oxidase-B), apolipoprotein E (involved in fat metabolism), and SAT1 (spermidine/spermine N1-acetyltransferase 1) [38,39]. SAT1 is a key catabolic 
enzyme for polyamines. Polyamine levels within cells control cell viability, while significant decreases in polyamine levels can result in apoptosis [40]. SAT1 is highly inducible by stress and cytokines [40]. In men reporting suicidal ideation, a high level of tumour necrosis factor (TNFSF10, ligand superfamily, Member 10) was observed in the blood [40]. For bipolar disorder, SLC4A4 (which regulates brain $\mathrm{pH}$ ) predicted suicidal ideation and future hospitalisation [38]. Numerous studies have identified insomnia and altered sleep architecture as predictors of suicidal thoughts and behaviour [41-43]. Figure 1 and Table 2 summarise the biological factors associated with suicidal behaviours.

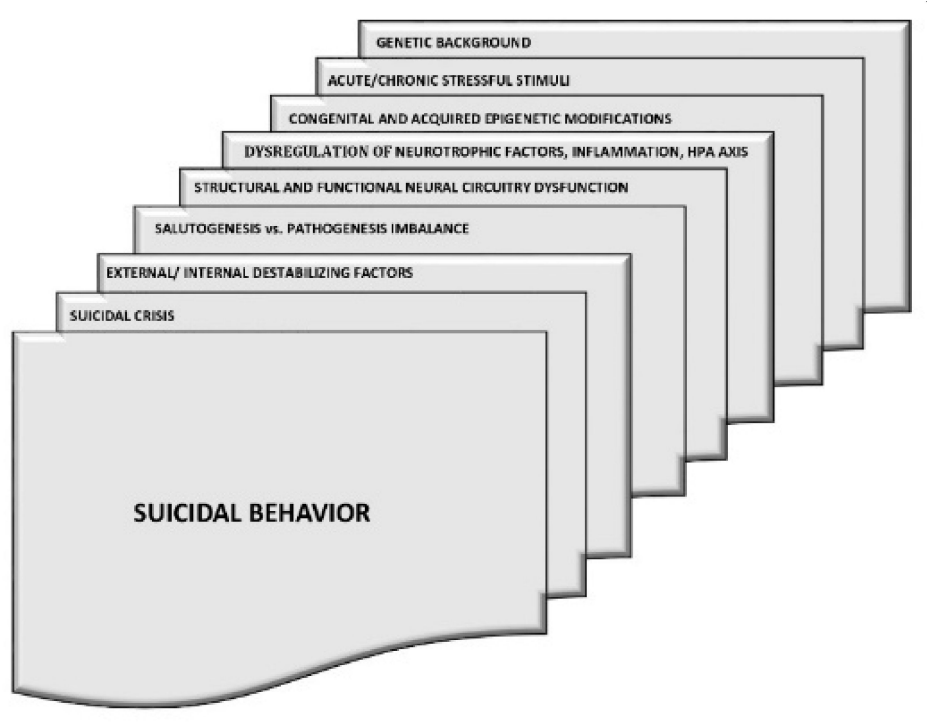

Figure 1. Biological factors that are likely to lead to suicidal behaviour.

Table 2. The selected potential markers of suicidal behaviour in prefrontal cortex, hippocampus, and peripheral tissue (blood or cerebrospinal fluid).

\begin{tabular}{|c|c|c|c|}
\hline & Prefrontal Cortex & Hippocampus & Peripheral Tissue \\
\hline 5-HIAA & - & $\uparrow$ & $\begin{array}{c}\text { CSF } \downarrow \\
\text { platelets } \downarrow\end{array}$ \\
\hline Serotonin transporter & $\downarrow$ & - & $\downarrow$ platelets \\
\hline GABA-A receptor & Contradictory information & $\uparrow$ & $\downarrow$ \\
\hline $\mathrm{CRH}$ & $\uparrow$ & $\uparrow$ & $\uparrow$ \\
\hline CRH receptor type 1 & $\downarrow$ & & \\
\hline Cortisol & No data & No data & $\uparrow$ plasma, CSF \\
\hline BDNF & $\downarrow$ & $\downarrow$ & $\downarrow$ serum \\
\hline IL-1 & $\uparrow$ & No data & $\uparrow$ blond \\
\hline IL-6 & $\uparrow$ & No data & $\uparrow$ blood, CSF \\
\hline IL-8 & - & No data & $\downarrow$ blood, CSF \\
\hline Quinolinic acid & $\uparrow$ & No data & CSF, blood $\uparrow$ \\
\hline Cholesterol & Decrease only in violence & - & $\downarrow$ \\
\hline DNA hypermethylation & $\uparrow$ & $\uparrow$ & $\uparrow$ \\
\hline miR-124, miR-139, miR-185, miR-195 & $\uparrow$ & No data & No data \\
\hline miR-494, miR-335 & $\downarrow$ & No data & No data \\
\hline miR-19a3p & $\uparrow$ & No data & Blood mononuclear cells $\uparrow$ \\
\hline
\end{tabular}

5-HIAA—5-hydroxyindoloacetic acid; 5HT—serotonin; GABA-A receptor- $\gamma$-aminobutyric acid receptor; CRH—corticotrophin releasing hormone; BDNF-brain-derived neurotrophic factor; IL-interleukin; CSF-cerebrospinal fluid, no changes. 


\subsection{Inflammation and the Kynurenine Pathway}

Inflammatory mediators play a critical role in the pathophysiology of suicide $[1,30,44]$. Suicidal patients display elevated markers of inflammation in the central nervous system and peripheral tissues, irrespective of their primary diagnosis, age, and gender [1,45].

A prospective study of 300,000 women (1000 of them later died due to suicide) revealed that a higher level of white cells was predictive of suicide [46]. CRP (C-reactive protein) acute-phase protein level in plasma has been correlated with suicidal intent, but not the number of attempts or severity of violence $[25,46,47]$. Inflammatory cytokines such as IL-1 beta and IL- 6 have been shown to be increased in the blood and CSF of suicidal patients $[44,48,49]$. Simultaneously, decreased neuroprotective IL-8 has been observed in the plasma and CSF of suicidal patients $[46,49]$. The messenger ribonucleic acid (mRNA) and protein levels of IL-1 $\beta$, IL- 6 , and TNF- $\alpha$ were abnormally elevated in the prefrontal cortex of young adults who died by suicide [49]. An elevated level of TNF- $\alpha$ was noticed in the dorsolateral prefrontal cortex of individuals who died by suicide, regardless of psychiatric diagnosis [23]; this observation supports the fact that interferon treatment increases the risk of depression and suicide [50,51]. It is worth mentioning that aberrant levels of proinflammatory cytokines are not specific to suicide but are also reported in major depressive disorder, bipolar disorder, and schizophrenia [52,53].

The importance of inflammation in suicide and depressive behaviour is also supported by observations and trials with nonsteroidal anti-inflammatory drugs (NSAIDs). Reports have suggested significantly less suicidal ideation in patients treated with ibuprofen, naproxen, celecoxib, or aspirin as compared with acetaminophen (paracetamol) [54]. Moreover, a meta-analysis of 36 randomised trials found that NSAID augmentation in patients with major depression improved antidepressants' treatment effects [55]. Most data suggest enhanced treatment response for celecoxib [56,57]. The effect is particularly evident in patients with elevated inflammation markers such as CRP [56]. Otherwise, it is also worth remembering that over the counter (OTC) NSAIDs are responsible for about $50 \%$ of suicidal attempts [58].

Another vital link between inflammation and suicidal behaviour is tryptophan metabolism via the kynurenine pathway [31]. The kynurenine pathway is responsible for over $90 \%$ degradation of tryptophan in the periphery and is present in many tissues such as the brain, liver, intestine, and immune cells [1]. The first step of the kynurenine pathway is converting tryptophan to $\mathrm{N}$-formylkynurenine by enzyme indoleamine-2,3-dioxygenase (IDO) or tryptophan 2,3 dioxygenase (TDO). In the following steps, kynurenine, quinolinic acid (QUIN), kynurenic acid (KYNA), and picolinic acid (PIC) are produced [1]. One of the final products of kynurenine is $\mathrm{NAD}^{+}$[59]. Proinflammatory cytokines such as IFN- $\gamma$, IL-1 $\beta$, and IL-6 activate the kynurenine pathway via stimulation of the IDO, which results in increased synthesis of quinolinic acid (QUIN) and/or kynurenic acid, and simultaneous depletion of serotonin and melatonin; therefore, QUIN levels could achieve neurotoxic level [31,48,59,60]. QUIN is a potent excitotoxin with NMDA agonistic activity [48]. The increased QUIN level produced by activated microglia might contribute to neuronal loss and reduced hippocampal volume [31]. QUIN can interact with free iron ions to form toxic complexes that exacerbate oxygen species radical formation, oxidative stress, and mitochondrial dysfunction [59]. In the CSF of suicide attempters and patients with suicidal intent, increased levels of QUIN were observed, regardless of mood disorder comorbidity [31,61]. The increase of QUIN in CSF patients who have recently attempted suicide was very potent, i.e., about $300 \%$ [31]. There was a significant correlation among CFS levels of QUIN acid, IL-6, and the suicidal ideation scores on the Suicide Intent Scale [31,47].

Moreover, as compared with nonviolent attempters, violent attempters have higher QUIN levels in their CSF [31]. Patients with suicide attempts and depression have higher kynurenine levels than patients with depression without suicide attempts $[1,31,62]$. Another metabolite of the kynurenic pathway is neuroprotective picolinic acid (PIC); its level was reduced in the CSF and blood of suicide attempters [48]. Similarly, suicide attempters have been characterised by a decreased PIC/QUIN ratio in their CSF and blood [48]. The 
reduction of PIC in the CSF was sustained over two years after a suicide attempt [48]. Further, anti-suicidal procedures, such as electroconvulsive therapy or ketamine can alter kynurenine metabolism, which suggest that this metabolic pathway may be helpful as a monitoring marker $[48,63]$.

\subsection{Serotonin System}

Serotonin deficits are implicated in pathogenesis of depression and also in aggression, impulsivity, suicidal ideations, and suicide attempts [3,35,64-66]. The CSF's lower levels of the major serotonin metabolite 5-hydroxyindoleacetic acid (5-HIAA) were found in suicide attempters with psychiatric disorders as compared with psychiatric non-attempters and healthy controls $[3,35,65,66]$. Moreover, lower levels of 5-HIAA in the CSF corresponded with the lethality of suicide attempt and predicted future suicide attempts and completion [3,67]. Lower 5-HIAA levels were also observed in platelets of suicidal patients [35]. Most studies of suicide victims have reported a decreased density of serotonin transporter in the prefrontal cortex, anterior cingulate, and hypothalamus, but some studies have shown no changes $[3,68,69]$. Most studies have reported that suicidal patients had upregulated expression of $5 \mathrm{HT}_{1 \mathrm{~A}}$ and $5 \mathrm{HT}_{2 \mathrm{~A}}$ receptors in the raphe and the prefrontal cortex, probably as a compensatory response to low activity of serotoninergic neurons. However, some studies have found no differences or even decreased $5 \mathrm{HT}_{1 \mathrm{~A}}$ and $5 \mathrm{HT}_{2 \mathrm{~A}}$ receptors expression. Moreover, increased expression of serotoninergic receptors has been observed in platelets $[3,30,35,70,71]$. This hypothesis suggests that depleted serotonin levels result from enhanced tryptophan metabolism to QUIN via the kynurenine pathway. Serotonin deficiency may decrease neurogenesis and lead to cognitive deficits. Moreover, studies have reported that polymorphisms of enzymes associated with serotonin synthesis and metabolism, such as tryptophan hydroxylase (polymorphism of intron 7) and MAO-A, were connected to suicide [72].

\subsection{Brain-Derived Neurotrophic Factor (BDNF)}

Suicidal patients are characterised by abnormal neuroplasticity [23,73]. Data indicate lower mRNA levels of BDNF and its receptor TrkB in the prefrontal cortex and hippocampus in suicide patients [74-76]. Moreover, downregulation of BDNF in the anterior cingulate cortex and amygdala, and lower serum BDNF levels, have been reported in depressed patients with suicidal intentions as compared with depressed patients without suicidal intentions $[30,73,75]$. Lower levels of BDNF in suicidal patients are probably the consequence of epigenetic modifications due to stress [75,76]. Some data suggest that serum levels of BDNF could be a promising marker of suicide [76], but others deny this finding [73].

\subsection{The Hypothalamic-Pituitary-Adrenal (HPA) Axis}

Suicidal behaviours seem to be associated with hyperactivity of the HPA axis, which may cause disturbed control of stress, impaired function of the hippocampus, and cognitive deficits [3]. Several studies have revealed that non-suppressors in dexamethasone test are more likely to commit suicide [35,77-79]. Adrenal gland cortical hypertrophy was highlighted in patients who died by suicide [80]. Higher cortisol levels in saliva, CSF, and plasma have been reported in suicide attempters than in healthy volunteers $[79,81]$. Depressed suicide patients had increased corticotrophin-releasing hormone (CRH) levels in the paraventricular nucleus of the hypothalamus, forebrain, locus coeruleus, and fewer $\mathrm{CRH}_{1}$ receptors in the frontopolar cortex [70,81,82] (Jokinen et al., 2018; Merali et al., 2004; Oquendo et al., 2014). Protein and gene expression of GR- $\alpha$ (glucocorticoid receptor) were significantly decreased in the prefrontal cortex and amygdala of teenage suicide victims as compared with controls $[69,83]$.

\subsection{Glutaminergic and GABAergic Neurotransmission}

The effectiveness of the glutaminergic NMDA receptor antagonists, ketamine/ esketamine, in decreasing suicide rates suggests the involvement of glutamate in this 
process. Existing data demonstrate that glutamate may play an important role in suiciderelated personality traits, including impulsivity and aggression [17]. This phenomenon could be associated with increased levels of the NMDA receptor agonist QUIN in the central nervous system of suicide attempters due to activation of the kynurenine pathway as a consequence of stimulation of IDO by proinflammatory cytokines [31]. Subsequently, most studies have reported decreases or no difference in NMDA binding in the prefrontal cortex in cases of suicide [70,84,85].

Data suggest a disturbed balance between glutaminergic and GABAergic neurotransmission in suicide risk. Nevertheless, there are some discrepancies in the research. Suicide victims are characterised by an increased expression of GABA-A receptors in the hippocampus and prefrontal cortex [86,87]. In addition, a pilot study examining the GABAergic system in suicide found decreased GABA-A gamma subunit expression in the prefrontal cortex of patients with depressive disorder and schizophrenia [88]. Data from a small group (12 suicide and 12 control participants) revealed decreased expression of $\alpha 1, \alpha 3, \alpha 4$, and $\delta$ mRNA GABA-A in the frontopolar cortex in depressed suicide victims [82]. Suicide victims had decreased GABA-A $\alpha 1$ receptor subunit expression in the frontal cortex [89]. Later studies have shown polymorphisms of the $\gamma-2$ subunit in suicide attempts, suggesting that the longest variant of the GABA-A receptor $\gamma-2$ subunit is associated with protection against suicide attempts [90]. In both suicidal adults and adolescents, decreased expression of GABA-A receptors on platelets was also found [91].

\subsection{Cholesterol}

Low cholesterol in plasma is associated with reduced lipid rafts in the central nervous system and subsequent reduced synaptic plasticity and decreased serotonin activity that could predispose to aggression $[67,92-94]$. Some studies have implied that lower cholesterol levels could be a useful biological marker in depression [95]. Interest in cholesterol as a biomarker for suicide has been growing since the early 1990s, when a meta-analysis of randomised primary prevention trials of statins (cholesterol-lowering drugs) indicated that they reduced the risk of death by coronary events but increased the risk of suicide $[96,97]$. On the one hand, a recent meta-analysis of 65 studies (comprising up to 500,000 participants) showed that suicidal patients had lower total cholesterol levels than non-suicidal controls, associated with a $112 \%$ higher risk of suicidality [96]. On the other hand, Molero et al. (2020) found in a cohort of 1,149,384 participants that statins were not associated with suicidality [98]. Limited evidence suggests lower brain levels of cholesterol in suicide attempters [99].

\section{Epigenetic Changes}

Epigenetic mechanisms can produce heritable phenotypic changes without a modification in DNA sequence. They include DNA methylation, histone modification (methylation or acethylation), and microRNA (miRNA) [100]. Epigenetic regulation of BDNF, TrkB, HPA axis components, and GABA-A receptors plays an important role in suicidal behaviour $[74,75,101]$. In suicide completers, increased expression of DNA methyltransferase (DNMT), the enzyme that methylates DNA in the frontal cortex, as well as total DNA hypermethylation in the Wernicki cortex and prefrontal cortex have been found $[74,75,79,102]$. Enhanced total methylation of the DNA in the blood has also been observed [103]. Higher methylation levels of the BDNF, GABA-A receptor subunits, and TrkB receptor promoters, as well as the NR3C1 gene (coding glucocorticoid receptor promoter), have been observed in suicide victims than in controls $[67,74,101]$. The low TrkB expression in suicide victims is probably due to multiple epigenetic consequences, such as hypermethylation of its promoter and higher histone methylation (H3K27) $[75,79]$. Lower BDNF protein levels in suicides in the prefrontal cortex and hippocampus are probably due to a decrease in histone acetylation [75].

Post-mortem brain studies suggest that miRNAs may be involved in suicide [104,105]. MiRNAs are non-coding, endogenous, short chain RNAs that inhibit mRNA translation into proteins and may regulate neuroplasticity associated with BDNF or CREB (cMP response 
element-binding) [105]. Some researchers have revealed the upregulation of miR-19a-3p in the peripheral blood mononuclear cells of depressed patients with suicidal ideation [23]. The prefrontal cortex showed significant upregulation of miR-124, miR-139, miR-185, and miR-195, while miR-494 and miR-335 were downregulated in patients with suicide $[23,106]$.

In summary, the epigenetic changes (especially methylation) of BDNF, HPA axis components, and GABA-A receptors play an important role in suicidal behaviour by regulating those proteins' expressions.

\section{Activity of Brain Structures in Suicidal Patients}

The frontal and prefrontal cortex plays an essential role in suicidal behaviour via its involvement in cognition, stress response, and suppression of impulsiveness $[76,107,108]$. Patients with a history of suicide attempts have altered prefrontal areas' activation patterns associated with impaired decision making, risk reward, and social assessment [47]. The anterior cingulate cortex responsible for negative self-thinking and processing of emotional stimuli is strongly implicated in suicidality [109]. Relative to depressed non-attempters, suicide attempters showed greater activation of the anterior cingulated cortex when viewing emotionally expressive faces, indicating different processing of emotional stimuli [47]. Studies using fMRI have confirmed the role of ventral and dorsal prefrontal cortex (PFC) dysfunction in suicide pathophysiology in response to emotional and hedonic valence stimuli [8]. Structural MRI studies have shown lower grey matter volume and neural density in the ventral PFC and reduced hippocampal volumes in adults who had attempted suicide than in psychiatric controls $[8,30]$.

Moreover, lower orbitofrontal activation during risky and safe choices is consistent with altered decision making [47]. In addition, the Nurses Global Assessment assessed abnormal resting-state functional connectivity in the frontolimbic system in patients with a higher risk of suicidality for suicidal risk with bipolar disorder [110].

\section{Therapeutic Options to Prevent Suicide}

Psychological treatments, pharmacotherapy (lithium, ketamine, esketamine, and clozapine), or electroconvulsive treatment reduce suicidal thoughts and behaviours [111-113]. There is no established effectiveness of drugs in preventing suicide [114,115]. However, drugs that exert evident anti-suicidal action exert joint anti-inflammatory action and increase the level of BDNF.

Some evidence suggests that psychological treatments (especially cognitive behavioural therapy) effectively reduce suicidal thoughts and behaviours, but their effect is seen to be deferred [45,116]. It is beneficial in the pediatric population [111]. Psychological interventions focus on strengthening skills in interpersonal communication, stress tolerance, and emotion regulation [45,117].

Electroconvulsive therapy (ECT) is safe and effective in reducing suicidal ideation in drug-resistant depression and schizophrenia in adults and adolescents, including population of pregnant women [118-120]. Interestingly, some data suggest that pre-ECT high level of TNF- $\alpha$ predicts a good response to ECT [121], and electroconvulsive therapy decreases inflammatory mediators [122].

\subsection{Lithium}

Lithium is a mood-stabilising drug with well-documented efficiency of anti-suicidal effects in drug-resistant depression and bipolar disorder [123-126]. A meta-analysis of 48 controlled trials (6674 participants) published by Ciprani et al. (2013) [127] found that lithium was more effective than a placebo in reducing the suicide rate in patients with depression. Long-term treatment with lithium reduced suicide attempts and deaths by approximately $20-60 \%$ in patients with depressive or bipolar disorders $[124,126,128]$. Lithium has been shown to decrease impulsivity, aggression, and cognitive decline in patients [26,124,129]; its action is probably connected to the neuroprotective effect on structures involved in emotional regulation, such as the prefrontal cortex. Lithium increases BDNF levels and reduces 
apoptotic processes $[26,124,129,130]$. Some studies have demonstrated that lithium inhibited microglial activation and exerted anti-inflammatory activity by inhibiting glycogen synthase kinase-3 (GSK3) [53,131]. It has been shown that inhibition of GSK-3 $\beta$ upregulated anti-inflammatory IL-10 production and reduced proinflammatory cytokines such as IL-1 $\beta$, IL-6, TNF, IL-12, and IFN- $\gamma$ activity $[53,131,132]$. A significant decrease in proinflammatory cytokines and attenuation of cyclooxygenase type 2 (COX-2) expression were evident after three months of lithium therapy $[53,131,133]$. The use of lithium to prevent suicide in depressed patients is limited due to its low therapeutic index and high toxicity [124]. During lithium therapy, adverse effects may occur which include thyroid insufficiency, kidney dysfunction, cardiac arrhythmia, neurologic symptoms, neurotoxicity delirium, and convulsions [134].

\subsection{Clozapine}

Clozapine is a second-line, atypical antipsychotic approved for drug-resistant schizophrenia that effectively reduces suicidality and aggression/impulsivity $[6,135]$. Despite clozapine toxicity, especially the risk of agranulocytosis, a meta-analysis showed that continuous clozapine treatment in schizophrenia was associated with a significantly lower long-term all-cause mortality rate compared to other antipsychotics [136]. Moreover, some observations suggest that the anti-suicidal effect of clozapine is present not only in schizophrenia but also in bipolar disorder and severe forms of borderline personality disorder [128]. In preclinical models, it was found that chronic administration of clozapine exerted an anti-inflammatory effect $[137,138]$.

\subsection{Ketamine/Esketamine}

Ketamine is a non-selective NMDA receptor antagonist used as an anaesthetic drug. Ketamine is a racemic mixture of $\mathrm{S}$ and $\mathrm{R}$ stereoisomers. Esketamine has a higher affinity for NMDA binding sites than the $\mathrm{R}$ isomer [6,139]. Ketamine and esketamine are the first pharmacological antidepressants with rapid and prolonged (3-14 days) action and an anti-suicidal effect in unipolar and bipolar depression $[6,67,139]$. The U.S. Food and Drug Administration (FDA) and European Medical Agency (EMA) registered intranasal esketamine in treating resistant depression with suicidal behaviour. Although ketamine is considered to be relatively safe, several side effects have been reported, such as agitation, dissociation, perceptual disturbance, abnormal sensations, increased blood pressure and increased heart rate, headache, and dizziness [140,141]. As compared with ECT, the ketamine is characterised by less cognitive impairment [142].

It has been found that ketamine reduced suicidal ideation in patients with depression and anxiety disorders [112,143]. The probable mechanism of action of ketamine is connected to the blockade of NMDA receptors and an increase in synaptic plasticity via the mTOR pathway and BDNF release $[48,139,140]$. Moreover, ketamine affects the kynurenine pathway and inhibits proinflammatory cytokine exacerbation $[144,145]$. Ketamine counteracts the increase in QUIN production induced by lipopolysaccharides (LPS) [139]. Ketamine has well-described effects on increasing total sleep and slow-wave sleep and reducing early-night awakening, which may be associated with ketamine anti-suicidal effects [144]. Ketamine also significantly impacts circadian rhythm systems via clock genes [144].

\section{Drugs That Increase the Risk of Suicidality}

Although antidepressants have a vital role in treating mood disorders, they present no evident anti-suicidal effect as compared with lithium, clozapine, and ketamine/ esketamine $[1,146,147]$. Moreover, in rare cases, they could induce or exacerbate suicidal tendencies, during the first weeks of treatment, especially in children and adolescents $[1,148]$. Some of selective serotonin reuptake inhibitors (SSRI) may increase suicidal behaviour by stimulating depressed patients to act with preexisting suicidal thoughts [149]. In 2004, the FDA issued a black box warning that using antidepressants was associated with an increased risk of suicidal ideation and behaviour in people under 18. In 2007, the 
notification was expanded to include young adults under 25. Similarly, the EMA scientific committee concluded, in 2005, that suicide-related behaviours and aggression were more frequently observed in clinical trials among children and adolescents treated with SSRIs than those treated with placebos.

Several case reports have described suicidal ideation in previously psychiatrically healthy individuals after treatment with interferon- $\beta$ [50].

In 2008, the FDA published a meta-analysis of 199 placebo-controlled trials of 11 anticonvulsant drugs. The FDA found that patients taking anticonvulsant drugs, such as gabapentin, tiagabine, and oxcarbazepine, had approximately twice the risk of suicidal behaviour or ideation as compared with patients receiving a placebo [150]. Epileptic patients appear to be at risk of developing treatment-induced psychiatric adverse effects [151].

\section{Substance Misuse}

Substance misuse is associated with an increased risk for suicide and suicide death [152-154]. Over 70\% of adolescent suicides may be linked to drug and alcohol abuse and dependence [155]. The highest risk is associated with multiple dependence on alcohol, drug, and tobacco [154]. Studies have demonstrated that substance-dependent patients had impulsive personality or coexisting psychiatric disorders, especially mood disorders [156,157]. Among addictive substances, the most implicated in suicide is alcohol. Clinical evidence implies that alcohol is the second cause of suicide after depression [10]. Acute and chronic alcohol consumption may both propel suicide attempts through various mechanisms, i.e., increasing dysphoria, aggressiveness, and impulsivity; constricting cognition; and impairing generation and implementation of alternative coping strategies [10]. People under the influence of alcohol choose more radical and effective methods of dying by suicide, for example, throwing themselves under a moving vehicle [158]. Moreover, chronic alcohol use decreases serotonergic neurotransmission, which may also be associated with suicide behaviour [66]. However, this risk is modulated by various factors, including sociodemographic, clinical, treatment-related, and life situational characteristics [159]. Adequate dependence treatment may decrease the risk of suicide [152]. Data suggest that other dependences, especially when they coexist, are associated with an increased risk of suicidal behaviour. For example, it has been found that frequent cannabis use was associated with increased incidence of suicidal ideation, plans, or attempts [160,161].

\section{Conclusions}

Suicidal behaviour is associated with multiple risk factors such as psychiatric disorders (mainly depression), personality traits (aggression, impulsivity, and pessimism), and stressful life events. Suicide scales allow for quick screening but provide insufficient predictive validity. Therefore, it is worth searching for potential biological markers. Our current knowledge about the neurobiology of suicide is still limited. The core element of suicide etiopathogenesis seems to be neuroinflammation that subsequently stimulates the kynurenine pathway and causes serotonin depletion, and increases the level of quinolinic acid (NMDA receptor agonist). These processes lead to glutamatergic overactivation and decrease the production of BDNF that worsen neuroplasticity. Suicidal behaviour is also associated with overactivity of the HPA axis, which can cause a sequence of impairments, including stress control or cognitive dysfunction. Epigenetic mechanisms control the above-described neurobiological changes associated with suicidal behaviour. Patients with a history of suicide have altered activation patterns of prefrontal areas and consequently impaired decision making, risk reward, and social assessment.

Fortunately, suicide risk could be attenuated by appropriate psychological treatment, electroconvulsive treatment, and drugs (lithium, ketamine, esketamine, clozapine). Lithium, ketamine, and esketamine have anti-suicidal effects in patients with unipolar or bipolar depression, while clozapine exerts such an effect in patients with schizophrenia. Their mechanisms of action are different, but their common mechanisms are anti- 
inflammatory and neuroprotective, confirming the critical role of neuroinflammation in suicide risk.

Author Contributions: Conceptualization, P.M., A.W.S. and K.K.; writing-original draft preparation, A.W.S.; writing-review and editing, P.M., K.K. and A.W.S.; funding acquisition, P.M. and A.W.S. All authors contributed to and have approved the final manuscript.

Funding: The study was supported by grant no. 2016/21/B/NZ7/02066 from the National Science Centre in Poland.

Institutional Review Board Statement: Not applicable.

Informed Consent Statement: Not applicable.

Data Availability Statement: No new data were created or analysed in this study.

Conflicts of Interest: The authors declare no conflict of interest.

\section{References}

1. Bryleva, E.Y.; Brundin, L. Kynurenine pathway metabolites and suicidality. Neuropharmacology 2017, 112, 324-330. [CrossRef] [PubMed]

2. Bachmann, S. Epidemiology of suicide and the psychiatric perspective. Int. J. Environ. Res. Public Health 2018, 15, 1425. [CrossRef]

3. Mann, J.J. Neurobiology of suicidal behaviour. Nat. Rev. Neurosci. 2003, 4, 819-828. [CrossRef] [PubMed]

4. Milner, A.; Sveticic, J.; De Leo, D. Suicide in the absence of mental disorder? A review of psychological autopsy studies across countries. Int. J. Soc. Psychiatry 2012, 59, 545-554. [CrossRef] [PubMed]

5. Roy, B.; Dwivedi, Y. Understanding epigenetic architecture of suicide neurobiology: A critical perspective. Neurosci. Biobehav. Rev. 2017, 72, 10-27. [CrossRef] [PubMed]

6. De Berardis, D.; Fornaro, M.; Valchera, A.; Cavuto, M.; Perna, G.; Di Nicola, M.; Serafini, G.; Carano, A.; Pompili, M.; Vellante, F.; et al. Eradicating suicide at its roots: Preclinical bases and clinical evidence of the efficacy of ketamine in the treatment of suicidal behaviors. Int. J. Mol. Sci. 2018, 19, 2888. [CrossRef]

7. Baldessarini, R.J. Epidemiology of suicide: Recent developments. Epidemiol. Psychiatr. Sci. 2019, 29, e71. [CrossRef]

8. Schmaal, L.; Van Harmelen, A.-L.; Chatzi, V.; Lippard, E.; Toenders, Y.J.; Averill, L.A.; Mazure, C.M.; Blumberg, H.P. Imaging suicidal thoughts and behaviors: A comprehensive review of 2 decades of neuroimaging studies. Mol. Psychiatry 2020, 25, 408-427. [CrossRef]

9. Bergfeld, I.O.; Mantione, M.; Figee, M.; Schuurman, P.R.; Lok, A.; Denys, D. Treatment-resistant depression and suicidality. J. Affect. Disord. 2018, 235, 362-367. [CrossRef]

10. Borges, G.; Bagge, C.L.; Cherpitel, C.J.; Conner, K.R.; Orozco, R.; Rossow, I. A meta-analysis of acute use of alcohol and the risk of suicide attempt. Psychol. Med. 2017, 47, 949-957. [CrossRef]

11. Chesney, E.; Goodwin, G.M.; Fazel, S. Risks of all-cause and suicide mortality in mental disorders: A meta-review. World Psychiatry 2014, 13, 153-160. [CrossRef]

12. Meltzer, H.Y.; Li, Z.; Kaneda, Y.; Ichikawa, J. Serotonin receptors their key role in drugs to treat schizophrenia. Prog. Neuropsychopharmacol. Biol. Psychiatry 2003, 27, 1159-1172. [CrossRef]

13. Mortensen, P.; Agerbo, E.; Erikson, T.; Qin, P.; Westergaard-Nielsen, N. Psychiatric illness and risk factors for suicide in Denmark. Lancet 2000, 355, 9-12. [CrossRef]

14. Breslau, N. Migraine, suicidal ideation, and suicide attempts. Neurology 1992, 42, 392. [CrossRef]

15. McFarland, D.; Walsh, L.; Napolitano, S.; Morita, J.; Jaiswal, R. Suicide in patients with cancer: Identifying the risk factors. Oncology 2019, 33, 221-226.

16. Calati, R.; Nemeroff, C.B.; Lopez-Castroman, J.; Cohen, L.J.; Galynker, I. Candidate biomarkers of suicide crisis syndrome: What to test next? A concept paper. Int. J. Neuropsychopharmacol. 2020, 23, 192-205. [CrossRef]

17. Jimenez-Trevino, L.; Gonzalez-Blanco, L.; Alvarez-Vazquez, C.; Rodriguez-Revuelta, J.; Martinez, P.A.S. Glutamine and new pharmacological targets to treat suicidal ideation. Curr. Top. Behav. Neurosci. 2020, 46, 179-196. [CrossRef] [PubMed]

18. Perroud, N.; Baud, P.; Mouthon, D.; Courtet, P.; Malafosse, A. Impulsivity, aggression and suicidal behavior in unipolar and bipolar disorders. J. Affect. Disord. 2011, 134, 112-118. [CrossRef] [PubMed]

19. Statham, D.J.; Heath, A.C.; Madden, P.A.F.; Bucholz, K.K.; Bierut, L.; Dinwiddie, S.H.; Slutske, W.S.; Dunne, M.; Martin, N. Suicidal behaviour: An epidemiological and genetic study. Psychol. Med. 1998, 28, 839-855. [CrossRef]

20. Mullins, N.; Bigdeli, T.B.; Børglum, A.D.; Coleman, J.R.I.; Demontis, D.; Mehta, D.; Power, R.A.; Ripke, S.; Stahl, E.A.; Starnawska, A.; et al. GWAS of suicide attempt in psychiatric disorders and association with major depression polygenic risk scores. Am. J. Psychiatry. 2019, 176, 651-660. [CrossRef] [PubMed]

21. Levey, D.; Polimanti, R.; Cheng, Z.; Zhou, H.; Nuñez, Y.Z.; Jain, S.; He, F.; Sun, X.; Ursano, R.J.; Kessler, R.C.; et al. Genetic associations with suicide attempt severity and genetic overlap with major depression. Transl. Psychiatry 2019, 9, 22. [CrossRef] 
22. Buchman-Schmitt, J.M.; Chu, C.; Michaels, M.S.; Hames, J.L.; Silva, C.; Hagan, C.R.; Ribeiro, J.D.; Selby, E.A.; Joiner, T.E. The role of stressful life events preceding death by suicide: Evidence from two samples of suicide decedents. Psychiatry Res. 2017, 256, 345-352. [CrossRef]

23. Dwivedi, Y. MicroRNAs in depression and suicide: Recent insights and future perspectives. J. Affect. Disord. 2018, 240, 146-154. [CrossRef]

24. Ganança, L.; Oquendo, M.A.; Tyrka, A.R.; Cisneros-Trujillo, S.; Mann, J.J.; Sublette, M.E. The role of cytokines in the pathophysiology of suicidal behavior. Psychoneuroendocrinology 2016, 63, 296-310. [CrossRef]

25. Lengvenyte, A.; Conejero, I.; Courtet, P.; Olié, E. Biological bases of suicidal behaviours: A narrative review. Eur. J. Neurosci. 2019, 10, 14635. [CrossRef] [PubMed]

26. Lenz, B.; Röther, M.; Bouna-Pyrrou, P.; Mühle, C.; Tektas, O.Y.; Kornhuber, J. The androgen model of suicide completion. Prog. Neurobiol. 2019, 172, 84-103. [CrossRef]

27. Killgore, W.D.; Cloonan, S.A.; Taylor, E.C.; Allbright, M.C.; Dailey, N.S. Trends in suicidal ideation over the first three months of COVID-19 lockdowns. Psychiatry Res. 2020, 293, 113390. [CrossRef] [PubMed]

28. O'Neill, S.; O'Connor, R.C. Suicide in Northern Ireland: Epidemiology, risk factors, and prevention. Lancet Psychiatry 2020, 7, 538-546. [CrossRef]

29. Allen, L.; Dwivedi, Y. MicroRNA mediators of early life stress vulnerability to depression and suicidal behavior. Mol. Psychiatry 2020, 25, 308-320. [CrossRef] [PubMed]

30. Orsolini, L.; Latini, R.; Pompili, M.; Serafini, G.; Volpe, U.; Vellante, F.; Fornaro, M.; Valchera, A.; Tomasetti, C.; Fraticelli, S.; et al. Understanding the complex of suicide in depression: From research to clinics. Psychiatry Investig. 2020, 17, 207-221. [CrossRef]

31. Erhardt, S.; Lim, E.; Linderholm, K.R.; Janelidze, S.; Lindqvist, D.; Samuelsson, M.; Lundberg, K.; Postolache, T.T.; TräskmanBendz, L.; Guillemin, G.; et al. Connecting inflammation with glutamate agonism in suicidality. Neuropsychopharmacology 2012, 38, 743-752. [CrossRef]

32. Sueki, H. Relationship between beck hopelessness scale and suicidal ideation: A short-term longitudinal study. Death Stud. 2020, 17, 1-6. [CrossRef]

33. Asarnow, J.; McArthur, D.; Hughes, J.; Barbery, V.; Berk, M. Suicide attempt risk in youths: Utility of the harkavy-asnis suicide scale for monitoring risk levels. Suicide Life-Threat. Behav. 2012, 42, 684-698. [CrossRef]

34. Ofek, H.; Weizman, T.; Apter, A. The child suicide potential scale: Inter-rater reliability and validity in Israeli in-patient adolescents. Isr. J. Psychiatry Relat. Sci. 1998, 35, 253-261.

35. Pandey, G.N.; Dwivedi, Y. Peripheral biomarkers for suicide. In The Neurobiological Basis of Suicide; Dwivedi, Y., Ed.; CRC Press: Boca Raton, FL, USA; Taylor \& Francis: Millton, UK, 2012.

36. Miura, H.; Ozaki, N.; Sawada, M.; Isobe, K.; Ohta, T.; Nagatsu, T. A link between stress and depression: Shifts in the balance between the kynurenine and serotonin pathways of tryptophan metabolism and the etiology and pathophysiology of depression. Stress 2008, 11, 198-209. [CrossRef]

37. Pandey, G.N. Biological basis of suicide and suicidal behavior. Bipolar Disord. 2013, 15, 524-541. [CrossRef]

38. Niculescu, A.B.; Levey, D.; Phalen, P.; Le-Niculescu, H.; Dainton-Howard, H.; Jain, N.; Belanger, E.; James, A.; George, S.; Weber, H.; et al. Understanding and predicting suicidality using a combined genomic and clinical risk assessment approach. Mol. Psychiatry 2015, 20, 1266-1285. [CrossRef]

39. Niculescu, A.B.; Le-Niculescu, H.; Levey, D.F.; Phalen, P.L.; Dainton, H.L.; Roseberry, K.; Niculescu, E.M.; Niezer, J.O.; Williams, A.; Graham, D.L.; et al. Precision medicine for suicidality: From universality to subtypes and personalisation. Mol. Psychiatry. 2017, 22, 1250-1273. [CrossRef]

40. Le-Niculescu, H.; Levey, D.; Ayalew, M.; Palmer, L.; Gavrin, L.M.; Jain, N.; Winiger, E.; Bhosrekar, S.; Shankar, G.; Radel, M.; et al. Discovery and validation of blood biomarkers for suicidality. Mol. Psychiatry 2013, 18, 1249-1264. [CrossRef]

41. Malik, S.; Kanwar, A.; Sim, L.A.; Prokop, L.J.; Wang, Z.; Benkhadra, K.; Murad, M.H. The association between sleep disturbances and suicidal behaviors in patients with psychiatric diagnoses: A systematic review and meta-analysis. Syst. Rev. $2014,3,18$. [CrossRef]

42. Lin, H.-T.; Lai, C.-H.; Perng, H.-J.; Chung, C.-H.; Wang, C.-C.; Chen, W.-L.; Chien, W.-C. Insomnia as an independent predictor of suicide attempts: A nationwide population-based retrospective cohort study. BMC Psychiatry 2018, 18, 117. [CrossRef]

43. Pigeon, W.R.; Pinquart, M.; Conner, K. Meta-analysis of sleep disturbance and suicidal thoughts and behaviors. J. Clin. Psychiatry 2012, 73, e1160-e1167. [CrossRef] [PubMed]

44. Amitai, M.; Taler, M.; Ben-Baruch, R.; Lebow, M.; Rotkopf, R.; Apter, A.; Fennig, S.; Weizman, A.; Chen, A. Increased circulatory IL-6 during 8-week fluoxetine treatment is a risk factor for suicidal behaviors in youth. Brain Behav. Immun. 2020, 87, 301-308. [CrossRef]

45. Cha, C.B.; Franz, P.J.; Guzmán, E.M.; Glenn, C.R.; Kleiman, E.M.; Nock, M.K. Annual research review: Suicide among youthepidemiology, (potential) etiology, and treatment. J. Child Psychol. Psychiatry 2017, 59, 460-482. [CrossRef] [PubMed]

46. Keaton, S.A.; Madaj, Z.B.; Heilman, P.; Smart, L.; Grit, J.; Gibbons, R.; Postolache, T.T.; Roaten, K.; Achtyes, E.D.; Brundin, L. An inflammatory profile linked to increased suicide risk. J. Affect. Disord. 2019, 247, 57-65. [CrossRef]

47. Sudol, K.; Mann, J.J. Biomarkers of sicide attempt behavior: Towards biological model of risk. Curr. Psychiatry. Rep. 2017, 19, 31. [CrossRef] 
48. Brundin, L.; Sellgren, C.M.; Lim, E.; Grit, J.; Palsson, E.; Landen, M.; Samuelsson, M.; Lundgren, K.; Brundin, P.; Fuchs, D.; et al. An enzyme in the kynurenine pathway that governs vulnerability to suicidal behavior by regulating excitotoxicity and neuroinflammation. Transl. Psychiatry 2016, 6, e865. [CrossRef]

49. Serafini, G.; Parisi, V.M.; Aguglia, A.; Amerio, A.; Sampogna, G.; Fiorillo, A.; Pompili, M.; Amore, M. A specific inflammatory profile underlying suicide risk? Systematic review of the main literature findings. Int. J. Environ. Res. Public Health 2020, 17, 2393. [CrossRef] [PubMed]

50. Fragoso, Y.D.; Comini-Frota, E.; Lopes, J.S.; Noal, J.S.; Giacomo, M.C.; Gomes, S.; Gonçalves, M.V.M.; da Gama, P.D.; Finkelsztejn, A. Severe depression, suicide attempts, and ideation during the use of interferon beta by patients with multiple sclerosis. Clin. Neuropharmacol. 2010, 33, 312-316. [CrossRef]

51. Sockalingam, S.; Links, P.S.; Abbey, S.E. Suicide risk in hepatitis $\mathrm{C}$ and during interferon-alpha therapy: A review and clinical update. J. Viral Hepat. 2010, 18, 153-160. [CrossRef]

52. Stuart, M.; Baune, B. Chemokines and chemokine receptors in mood disorders, schizophrenia, and cognitive impairment: A systematic review of biomarker studies. Neurosci. Biobehav. Rev. 2014, 42, 93-115. [CrossRef]

53. Nassar, A.; Azab, A.N. Effects of lithium on inflammation. ACS Chem. Neurosci. 2014, 5, 451-458. [CrossRef] [PubMed]

54. Lehrer, S.; Rheinstein, P. Nonsteroidal anti-inflammatory drugs (NSAIDs) reduce suicidal ideation and depression. Discov. Med 2019, 28, 205-212.

55. Köhler-Forsberg, O.; Lydholm, C.N.; Hjorthøj, C.; Nordentoft, M.; Mors, O.; Benros, M. Efficacy of anti-inflammatory treatment on major depressive disorder or depressive symptoms: Meta-analysis of clinical trials. Acta Psychiatr. Scand. 2019, 139, 404-419. [CrossRef]

56. Fourrier, C.; Sampson, E.; Mills, N.; Baune, B.T. Anti-inflammatory treatment of depression: Study protocol for a randomised controlled trial of vortioxetine augmented with celecoxib or placebo. Trials 2018, 19, 447. [CrossRef]

57. Halaris, A.; Cantos, A.; Johnson, K.; Hakimi, M.; Sinacore, J. Modulation of the inflammatory response benefits treatment-resistant bipolar depression: A randomized clinical trial. J. Affect. Disord. 2020, 261, 145-152. [CrossRef]

58. Hopkins, A.G.; Spiller, H.A.; Kistamgari, S.; Zhu, M.; Michaels, N.L.; Funk, A.R.; Smith, G.A. Suicide-related over-the-counter analgesic exposures reported to United States poison control centers, 2000-2018. Pharmacoepidemiol. Drug. Saf. 2020, 29, 1011-1021. [CrossRef]

59. Sas, K.; Szabó, E.; Vécsei, L. Mitochondria, oxidative stress and the kynurenine system, with a focus on ageing and neuroprotection. Molecules 2018, 23, 191. [CrossRef]

60. Tufvesson-Alm, M.; Schwieler, L.; Schwarcz, R.; Goiny, M.; Erhardt, S.; Engberg, G. Importance of kynurenine 3-monooxygenase for spontaneous firing and pharmacological responses of midbrain dopamine neurons: Relevance for schizophrenia. Neuropharmacology 2018, 138, 130-139. [CrossRef]

61. Hardingham, G.; Fukunaga, Y.; Bading, H. Extrasynaptic NMDARs oppose synaptic NMDARs by triggering CREB shut-off and cell death pathways. Nat. Neurosci. 2002, 5, 405-414. [CrossRef] [PubMed]

62. Sublette, M.E.; Galfalvy, H.; Fuchs, D.; Lapidus, M.; Grunebaum, M.F.; Oquendo, M.A.; Mann, J.J.; Postolache, T.T. Plasma kynurenine levels are elevated in suicide attempters with major depressive disorder. Brain Behav. Immun. 2011, 25, 1272-1278. [CrossRef]

63. Savitz, J. The kynurenine pathway: A finger in every pie. Mol. Psychiatry 2020, 25, 131-147. [CrossRef]

64. Arango, V.; Underwood, M.; Boldrini, M.; Tamir, H.; Kassir, S.A.; Hsiung, S.-C.; Chen, J.J.-X.; Mann, J.J. Serotonin 1A receptors, serotonin transporter binding and serotonin transporter mRNA expression in the brainstem of depressed suicide victims. Neuropsychopharmacology 2001, 25, 892-903. [CrossRef]

65. Asberg, M.; Träskman, L.; Thorén, P. 5-HIAA in the cerebrospinal fluid. A biochemical suicide predictor? Arch. Gen. Psychiatry. 1976, 33, 1193-1197. [CrossRef] [PubMed]

66. Sher, L.; Carballo, J.J.; Grunebaum, M.F.; Burke, A.K.; Zalsman, G.; Huang, Y.-Y.; Mann, J.J.; Oquendo, M.A. A prospective study of the association of cerebrospinal fluid monoamine metabolite levels with lethality of suicide attempts in patients with bipolar disorder. Bipolar Disord. 2006, 8, 543-550. [CrossRef]

67. Mathews, D.C.; Richards, E.M.; Niciu, M.J.; Ionescu, D.F.; Rasimas, J.J.; Zarate, C.A. Neurobiological aspects of suicide and suicide attempts in bipolar disorder. Transl. Neurosci. 2013, 4, 203-216. [CrossRef]

68. Antypa, N.; Serretti, A.; Rujescu, D. Serotonergic genes and suicide: A systematic review. Eur. Neuropsychopharmacol. 2013, $23,1125-1142$. [CrossRef] [PubMed]

69. Pandey, G.N.; Rizavi, H.S.; Ren, X.; Dwivedi, Y.; Palkovits, M. Region-specific alterations in glucocorticoid receptor expression in the postmortem brain of teenage suicide victims. Psychoneuroendocrinology 2013, 38, 2628-2639. [CrossRef]

70. Oquendo, M.A.; Sullivan, G.M.; Sudol, K.; Baca-García, E.; Stanley, B.H.; Sublette, M.E.; Mann, J.J. Toward a biosignature for suicide. Am. J. Psychiatry 2014, 171, 1259-1277. [CrossRef]

71. Stockmeier, C.A.; Dilley, G.E.; Shapiro, L.A.; Overholser, J.C.; Thompson, P.A.; Meltzer, H.Y. Serotonin receptors in suicide victims with major depression. Neuropsychopharmacology 1997, 16, 162-173. [CrossRef]

72. Bennett, P.J.; McMahon, W.M.; Watabe, J.; Achilles, J.; Bacon, M.; Coon, H.; Grey, T.; Keller, T.; Tate, D.; Tcaciuc, I.; et al. Tryptophan hydroxylase polymorphisms in suicide victims. Psychiatr. Genet. 2000, 10, 13-17. [CrossRef] [PubMed]

73. Eisen, R.B.; Perera, S.; Banfield, L.; Anglin, R.; Minuzzi, L.; Samaan, Z. Association between BDNF levels and suicidal behaviour: A systematic review and meta-analysis. Syst. Rev. 2015, 4, 187. [CrossRef] 
74. Autry, A.E.; Monteggia, L.M. Epigenetics in suicide and depression. Biol. Psychiatry 2009, 66, 812-813. [CrossRef]

75. Misztak, P.; Pańczyszyn-Trzewik, P.; Nowak, G.; Sowa-Kućma, M. Epigenetic marks and their relationship with BDNF in the brain of suicide victims. PLoS ONE 2020, 15, e0239335. [CrossRef]

76. Salas-Magaña, M.; Tovilla-Zárate, C.A.; González-Castro, T.B.; Juárez-Rojop, I.E.; López-Narváez, M.L.; Rodríguez-Pérez, J.M.; Ramírez-Bello, J. Decrease in brain-derived neurotrophic factor at plasma level but not in serum concentrations in suicide behavior: A systematic review and meta-analysis. Brain Behav. 2017, 7, e00706. [CrossRef] [PubMed]

77. Pompili, M.; Serafini, G.; Innamorati, M.; Möller-Leimkühler, A.M.; Giupponi, G.; Girardi, P.; Tatarelli, R.; Lester, D. The hypothalamic-pituitary-adrenal axis and serotonin abnormalities: A selective overview for the implications of suicide prevention. Eur. Arch. Psychiatry Clin. Neurosci. 2010, 260, 583-600. [CrossRef] [PubMed]

78. Yerevanian, B.I.; Koek, R.J.; Feusner, J.D.; Hwang, S.; Mintz, J. Antidepressants and suicidal behaviour in unipolar depression. Acta Psychiatr. Scand. 2004, 110, 452-458. [CrossRef] [PubMed]

79. Turecki, G. Epigenetics and suicidal behavior research pathways. Am. J. Prev. Med. 2014, 47, S144-S151. [CrossRef]

80. Berardelli, I.; Serafini, G.; Cortese, N.; Fiaschè, F.; O'Connor, R.C.; Pompili, M. The involvement of hypothalamus-pituitary-adrenal (HPA) axis in suicide risk. Brain Sci. 2020, 10, 653. [CrossRef]

81. Jokinen, J.; Boström, A.E.; Dadfar, A.; Ciuculete, D.M.; Chatzittofis, A.; Åsberg, M.; Schiöth, H.B. Epigenetic changes in the CRH gene are related to severity of suicide attempt and a general psychiatric risk score in adolescents. EBioMedicine 2018, 27, 123-133. [CrossRef]

82. Merali, Z.; Du, L.; Hrdina, P.; Palkovits, M.; Faludi, G.; Poulter, M.O.; Anisman, H. Dysregulation in the suicide brain: mRNA expression of corticotropin-releasing hormone receptors and GABA (A) receptor subunits in frontal cortical brain region. J. Neurosci. 2004, 24, 1478-1485. [CrossRef]

83. Pandey, G.N.; Rizavi, H.S.; Bhaumik, R.; Ren, X. Increased protein and mRNA expression of corticotropin-releasing factor $(\mathrm{CRF})$, decreased CRF receptors and CRF binding protein in specific postmortem brain areas of teenage suicide subjects. Psychoneuroendocrinology 2019, 106, 233-243. [CrossRef] [PubMed]

84. Gaynor, S.C.; Breen, M.E.; Monson, E.T.; de Klerk, K.; Parsons, M.; DeLuca, A.P.; Scheetz, T.; Zandi, P.P.; Potash, J.B.; Willour, V.L. A targeted sequencing study of glutamatergic candidate genes in suicide attempters with bipolar disorder. Am. J. Med. Genet. Part B Neuropsychiatr. Genet. 2016, 171, 1080-1087. [CrossRef]

85. Sowa-Kućma, M.; Szewczyk, B.; Sadlik, K.; Piekoszewski, W.; Trela, F.; Opoka, W.; Poleszak, E.; Pilc, A.; Nowak, G. Zinc, magnesium and NMDA receptor alterations in the hippocampus of suicide victims. J. Affect. Disord. 2013, 151, 924-931. [CrossRef]

86. Kim, S.; Choi, K.-H.; Baykiz, A.F.; Gershenfeld, H.K. Suicide candidate genes associated with bipolar disorder and schizophrenia: An exploratory gene expression profiling analysis of post-mortem prefrontal cortex. BMC Genom. 2007, 8, 413. [CrossRef]

87. Sequeira, A.; Mamdani, F.; Ernst, C.; Vawter, M.P.; Bunney, W.E.; Lebel, V.; Rehal, S.; Klempan, T.; Gratton, A.; Benkelfat, C.; et al. Global brain gene expression analysis links glutamatergic and GAB aergic alterations to suicide and major depression. PLoS ONE 2009, 4, e6585. [CrossRef]

88. Yin, H.; Pantazatos, S.P.; Galfalvy, H.; Huang, Y.Y.; Rosoklija, G.B.; Dwork, A.J.; Burke, A.; Arango, V.; Oquendo, M.A.; Mann, J.J. A pilot integrative genomics study of GABA and glutamate neurotransmitter systems in suicide, suicidal behavior, and major depressive disorder. Am. J. Med. Genet. B Neuropsychiatr. Genet. 2016, 171B, 414-426. [CrossRef]

89. Poulter, M.O.; Du, L.; Zhurov, V.; Palkovits, M.; Faludi, G.; Merali, Z.; Anisman, H. Altered organization of GABAA receptor mRNA expression in the depressed suicide brain. Front. Mol. Neurosci. 2010, 3, 3. [CrossRef] [PubMed]

90. Yin, H.; Galfalvy, H.; Zhang, B.; Tang, W.; Xin, Q.; Li, E.; Xue, X.; Li, Q.; Ye, J.; Yan, N.; et al. Interactions of the GABRG2 polymorphisms and childhood trauma on suicide attempt and related traits in depressed patients. J. Affect. Disord. 2020, 266, 447-455. [CrossRef] [PubMed]

91. Soreni, N.; Apter, A.; Weizman, A.; Don-Tufeled, O.; Leschiner, S.; Karp, L.; Gavish, M. Decreased platelet peripheral-type benzodiazepine receptors in adolescent inpatients with repeated suicide attempts. Biol. Psychiatry 1999, 46, 484-488. [CrossRef]

92. Brunner, J.; Parhofer, K.G.; Schwandt, P.; Bronisch, T. Cholesterol, omega-3 fatty acids, and suicide risk: Empirical evidence and pathophysiological hypotheses. Fortschr. Neurol. Psychiatr. 2001, 69, 460-467. [CrossRef] [PubMed]

93. Kunugi, H.; Takei, N.; Aoki, H.; Nanko, S. Low serum cholesterol in suicide attempters. Biol. Psychiatry 1997, 41, 196-200. [CrossRef]

94. Sublette, M.E. Lipids and suicide risk. Curr. Top. Behav. Neurosci. 2020, 46, 155-177. [PubMed]

95. Kim, Y.K.; Myint, A.M. Clinical application of low serum cholesterol as an indicator for suicide risk in major depression. J. Affect. Disord. 2004, 81, 161-166. [CrossRef]

96. Knowles, E.E.M.; Curran, J.E.; Meikle, P.; Huynh, K.; Mathias, S.R.; Göring, H.H.H.; VandeBerg, J.L.; Mahaney, M.C.; Jalbrzikowski, M.; Mosior, M.K.; et al. Disentangling the genetic overlap between cholesterol and suicide risk. Neuropsychopharmacology 2018, 43, $2556-2563$. [CrossRef]

97. Muldoon, M.F.; Manuck, S.B.; Matthews, K.A. Lowering cholesterol concentrations and mortality: A quantitative review of primary prevention trials. BMJ 1990, 301, 309-314. [CrossRef]

98. Molero, Y.; Cipriani, A.; Larsson, H.; Lichtenstein, P.; D'Onofrio, B.M.; Fazel, S. Associations between statin use and suicidality, depression, anxiety, and seizures: A Swedish total-population cohort study. Lancet Psychiatry 2020, 7, 982-990. [CrossRef] 
99. Freemantle, E.; Chen, G.G.; Cruceanu, C.; Mechawar, N.; Turecki, G. Analysis of oxysterols and cholesterol in prefrontal cortex of suicides. Int. J. Neuropsychopharmacol. 2013, 16, 1241-1249. [CrossRef]

100. Zhang, L.; Lu, Q.; Chang, C. Epigenetics in health and disease. Adv. Exp. Med. Biol. 2020, 1253, 3-55. [CrossRef]

101. Kouter, K.; Zupanc, T.; Paska, A.V. Genome-wide DNA methylation patterns in suicide victims: Identification of new candidate genes. Psychiatr. Danub. 2019, 31, 392-396. [CrossRef]

102. Poulter, M.O.; Du, L.; Weaver, I.; Palkovits, M.; Faludi, G.; Merali, Z.; Szyf, M.; Anisman, H. GABAA receptor promoter hypermethylation in suicide brain: Implications for the involvement of epigenetic processes. Biol. Psychiatry 2008, 64, 645-652. [CrossRef]

103. Murphy, T.M.; Mullins, N.; Ryan, M.; Foster, T.; Kelly, C.; McClelland, R.; O’Grady, J.; Corcoran, E.; Brady, J.; Reilly, M.; et al. Genetic variation in DNMT3B and increased global DNA methylation is associated with suicide attempts in psychiatric patients. Genes. Brain. Behav. 2013, 12, 125-132. [CrossRef]

104. Squassina, A.; Niola, P.; Lopez, J.P.; Cruceanu, C.; Pisanu, C.; Congiu, D.; Severino, G.; Ardau, R.; Chillotti, C.; Alda, M.; et al. MicroRNA expression profiling of lymphoblasts from bipolar disorder patients who died by suicide, pathway analysis and integration with postmortem brain findings. Eur. Neuropsychopharmacol. 2020, 34, 39-49. [CrossRef] [PubMed]

105. Roy, B.; Yoshino, Y.; Allen, L.; Prall, K.; Schell, G.; Dwivedi, Y. Exploiting circulating microRNAs as biomarkers in psychiatric disorders. Mol. Diagn. Ther. 2020, 24, 279-298. [CrossRef]

106. Smalheiser, N.R.; Lugli, G.; Rizavi, H.S.; Torvik, V.I.; Turecki, G.; Dwivedi, Y. MicroRNA expression is down-regulated and reorganised in prefrontal cortex of depressed suicide subjects. PLoS ONE 2012, 7, e33201. [CrossRef] [PubMed]

107. Klempan, T.A.; Sequeira, A.; Canetti, L.; Lalovic, A.; Ernst, C.; Ffrench-Mullen, J.; Turecki, G. Altered expression of genes involved in ATP biosynthesis and GABAergic neurotransmission in the ventral prefrontal cortex of suicides with and without major depression. Mol. Psychiatry 2007, 14, 175-189. [CrossRef] [PubMed]

108. Miller, E.K.; Cohen, J.D. An integrative theory of prefrontal cortex function. Annu. Rev. Neurosci. 2001, 24, 167-202. [CrossRef]

109. Lewis, C.P.; Port, J.D.; Blacker, C.J.; Sonmez, A.I.; Seewoo, B.; Leffler, J.M.; Frye, M.A.; Croarkin, P.E. Altered anterior cingulate glutamatergic metabolism in depressed adolescents with current suicidal ideation. Transl. Psychiatry 2020, 10, 119. [CrossRef]

110. Zhu, R.; Tian, S.; Wang, H.; Jiang, H.; Wang, X.; Shao, J.; Wang, Q.; Yan, R.; Tao, S.; Liu, H.; et al. Discriminating suicide attempters and predicting suicide risk using altered frontolimbic resting-state functional connectivity in patients with bipolar II disorder. Front. Psychiatry 2020, 11, 597770. [CrossRef]

111. Guzzetta, F.; Tondo, L.; Centorrino, F.; Baldessarini, R.J. Lithium treatment reduces suicide risk in recurrent major depressive disorder. J. Clin. Psychiatry 2007, 68, 380-383. [CrossRef]

112. Turecki, G.; Brent, D.A. Suicide and suicidal behaviour. Lancet 2016, 387, 1227-1239. [CrossRef]

113. Zarate, C.A., Jr.; Brutsche, N.E.; Ibrahim, L.; Franco-Chaves, J.; Diazgranados, N.; Cravchik, A.; Selter, J.; Marquardt, C.A.; Liberty, V.; Luckenbaugh, D.A. Replication of ketamine's antidepressant efficacy in bipolar depression: A randomised controlled add-on trial. Biol. Psychiatry 2012, 71, 939-946. [CrossRef]

114. Brown, G.K.; Have, T.T.; Henriques, G.R.; Xie, S.X.; Hollander, J.; Beck, A.T. Cognitive therapy for the prevention of suicide attempts. JAMA 2005, 294, 563-570. [CrossRef] [PubMed]

115. King, C.A.; Arango, A.; Foster, C.E. Emerging trends in adolescent suicide prevention research. Curr. Opin. Psychol. 2018, $22,89-94$. [CrossRef]

116. Fazel, S.; Runeson, B. Suicide. N. Engl. J. Med. 2020, 382, 266-274. [CrossRef] [PubMed]

117. Cwik, M.F.; O'Keefe, V.M.; Haroz, E.E. Suicide in the pediatric population: Screening, risk assessment and treatment. Int. Rev. Psychiatry 2020, 32, 254-264. [CrossRef] [PubMed]

118. Peltzman, T.; Shiner, B.; Watts, B.V. Effects of electroconvulsive therapy on short-term suicide mortality in a risk-matched patient population. J. ECT 2020, 36, 187-192. [CrossRef]

119. Calaway, K.; Coshal, S.; Jones, K.; Coverdale, J.; Livingston, R. A systematic review of the safety of electroconvulsive therapy use during the first trimester of pregnancy. J. ECT 2016, 32, 230-235. [CrossRef]

120. Pompili, M.; Dominici, G.; Giordano, G.; Longo, L.; Serafini, G.; Lester, D.; Amore, M.; Girardi, P. Electroconvulsive treatment during pregnancy: A systematic review. Expert Rev. Neurother. 2014, 14, 1377-1390. [CrossRef] [PubMed]

121. Pinna, M.; Manchia, M.; Oppo, R.; Scano, F.; Pillai, G.; Loche, A.P.; Salis, P.; Minnai, G.P. Clinical and biological predictors of response to electroconvulsive therapy (ECT): A review. Neurosci. Lett. 2018, 669, 32-42. [CrossRef] [PubMed]

122. Bioque, M.; Mac-Dowell, K.S.; Meseguer, A.; Macau, E.; Valero, R.; Vieta, E.; Leza, J.C.; Bernardo, M. Effects of electroconvulsive therapy in the systemic inflammatory balance of patients with severe mental disorder. Psychiatry Clin. Neurosci. 2019, 73, 628-635. [CrossRef]

123. Baldessarini, R.J.; Tondo, L.; Davis, P.; Pompili, M.; Goodwin, F.K.; Hennen, J. Decreased risk of suicides and attempts during long-term lithium treatment: A meta-analytic review. Bipolar Disord. 2007, 8, 625-639. [CrossRef] [PubMed]

124. Benard, V.; Vaiva, G.; Masson, M.; Geoffroy, P. Lithium and suicide prevention in bipolar disorder. L’Encéphale 2016, 42, $234-241$. [CrossRef]

125. Smith, K.A.; Cipriani, A. Lithium and suicide in mood disorders: Updated meta-review of the scientific literature. Bipolar Disord. 2017, 19, 575-586. [CrossRef] [PubMed]

126. Wada, A. Lithium and neuropsychiatric therapeutics: Neuroplasticity via. glycogen synthase kinase-3beta, beta-catenin, and neurotrophin cascades. J. Pharmacol. Sci. 2009, 110, 14-28. [CrossRef] [PubMed] 
127. Cipriani, A.; Hawton, K.; Stockton, S.; Geddes, J.R. Lithium in the prevention of suicide in mood disorders: Updated systematic review and meta-analysis. BMJ 2013, 346, f3646. [CrossRef]

128. Wilkowska, A.; Wiglusz, M.; Cubała, W.J. Clozapine: Promising treatment for suicidality in bipolar disorder. Psychiatr. Danub 2019, 31, 574-578.

129. Tondo, L.; Baldessarini, R.J. Antisuicidal effects in mood disorders: Are they unique to lithium? Pharmacopsychiatry 2018, 51, 177-188 [CrossRef] [PubMed]

130. Malhi, G.S.; Tanious, M.; Das, P.; Coulston, C.M.; Berk, M. Potential mechanisms of action of lithium in bipolar disorder. CNS Drugs 2013, 27, 135-153. [CrossRef] [PubMed]

131. Beurel, E.; Jope, R.S. Inflammation and lithium: Clues to mechanisms contributing to suicide-linked traits. Transl. Psychiatry 2014, 4, e488. [CrossRef] [PubMed]

132. Rapaport, M.H.; Manji, H.K. The effects of lithium on ex vivo cytokine production. Biol. Psychiatry 2001, 50, 217-224. [CrossRef]

133. Bosetti, F.; Rintala, J.; Seemann, R.; Rosenberger, T.; Contreras, M.A.; Rapoport, S.I.; Chang, M.C. Chronic lithium downregulates cyclooxygenase-2 activity and prostaglandin $\mathrm{E}_{2}$ concentration in rat brain. Mol. Psychiatry 2002, 7, 845-850. [CrossRef] [PubMed]

134. Griffiths, J.J.; Zarate, C.A., Jr.; Rasimas, J.J. Existing and novel biological therapeutics in suicide prevention. Am. J. Prev. Med. 2014, 47, S195-S203. [CrossRef] [PubMed]

135. Spivak, B.; Roitman, S.; Vered, Y.; Mester, R.; Graff, E.; Talmon, Y.; Guy, N.; Gonen, N.; Weizman, A. Diminished suicidal and aggressive behavior, high plasma norepinephrine levels, and serum triglyceride levels in chronic neuroleptic-resistant schizophrenic patients maintained on clozapine. Clin. Neuropharmacol. 1998, 21, 245-250.

136. Vermeulen, J.M.; van Rooijen, G.; van de Kerkhof, M.P.J.; Sutterland, A.L.; Correll, C.U.; de Haan, L. Clozapine and long-term mortality risk in patients with schizophrenia: A systematic review and meta-analysis of studies lasting 1.1-12.5 years. Schizophr. Bull. 2019, 45, 315-329. [CrossRef] [PubMed]

137. Ceresoli-Borroni, G.; Rassoulpour, A.; Wu, H.-Q.; Guidetti, P.; Schwarcz, R. Chronic neuroleptic treatment reduces endogenous kynurenic acid levels in rat brain. J. Neural Transm. 2006, 113, 1355-1365. [CrossRef]

138. Pandurangi, A.K.; Buckley, P.F. Inflammation, antipsychotic drugs, and evidence for effectiveness of anti-inflammatory agents in schizophrenia. Curr. Top. Behav. Neurosci. 2019, 44, 227-244. [CrossRef]

139. Gould, T.D.; Zarate, C.A., Jr.; Thompson, S.M. Molecular pharmacology and neurobiology of rapid-acting antidepressants. Annu. Rev. Pharmacol. Toxicol. 2019, 59, 213-236. [CrossRef] [PubMed]

140. Duman, R.S. Ketamine and rapid-acting antidepressants: A new era in the battle against depression and suicide. F1000Research 2018, 7, 659. [CrossRef]

141. Ramadan, A.M.; Mansour, I.A. Could ketamine be the answer to treating treatment-resistant major depressive disorder? Gen. Psychiatr. 2020, 33, e100227. [CrossRef]

142. Veraart, J.K.; Smith-Apeldoorn, S.Y.; Spaans, H.-P.; Kamphuis, J.; Schoevers, R.A. Is ketamine an appropriate alternative to ECT for patients with treatment resistant depression? A systematic review. J. Affect. Disord. 2021, 281, 82-89. [CrossRef] [PubMed]

143. Ballard, E.D.; Ionescu, D.F.; Vande Voort, J.L.; Niciu, M.J.; Richards, E.M.; Luckenbaugh, D.A.; Brutsché, N.E.; Ameli, R.; Furey, M.L.; Zarate, C.A., Jr. Improvement in suicidal ideation after ketamine infusion: Relationship to reductions in depression and anxiety. J. Psychiatr. Res. 2014, 58, 161-166. [CrossRef]

144. Matveychuk, D.; Thomas, R.K.; Swainson, J.; Khullar, A.; Mackay, M.-A.; Baker, G.B.; Dursun, S.M. Ketamine as an antidepressant: Overview of its mechanisms of action and potential predictive biomarkers. Ther. Adv. Psychopharmacol. 2020, 10, 2045125320916657. [CrossRef]

145. Verdonk, F.; Petit, A.-C.; Abdel-Ahad, P.; Vinckier, F.; Jouvion, G.; de Maricourt, P.; De Medeiros, G.F.; Danckaert, A.; Van Steenwinckel, J.; Blatzer, M.; et al. Microglial production of quinolinic acid as a target and a biomarker of the antidepressant effect of ketamine. Brain Behav. Immun. 2019, 81, 361-373. [CrossRef] [PubMed]

146. Isacsson, G.; Rich, C.L. Antidepressant drugs and the risk of suicide in children and adolescents. Pediatr. Drugs 2014, 16, 115-122. [CrossRef] [PubMed]

147. Teicher, M.H.; Glod, C.A.; Cole, J.O. Antidepressant drugs and the emergence of suicidal tendencies. Drug Saf. 1993, 8, 186-212. [CrossRef]

148. Hammad, T.A.; Laughren, T.; Racoosin, J. Suicidality in pediatric patients treated with antidepressant drugs. Arch. Gen. Psychiatry 2006, 63, 332-339. [CrossRef]

149. Müller-Oerlinghausen, B.; Berghöfer, A. Antidepressants and suicidal risk. J. Clin. Psychiatry 1999, 60, 94-99. [PubMed]

150. Patorno, E.; Bohn, R.L.; Wahl, P.M.; Avorn, J.; Patrick, A.R.; Liu, J.; Schneeweiss, S. Anticonvulsant medications and the risk of suicide, attempted suicide, or violent death. JAMA 2010, 303, 1401-1409. [CrossRef]

151. Mula, M.; Sander, J.W. Suicide risk in people with epilepsy taking antiepileptic drugs. Bipolar Disord. 2013, 15, 622-627. [CrossRef] [PubMed]

152. Fruhbauerova, M.; Comtois, K.A. Addiction counselors and suicide: Education and experience do not improve suicide knowledge, beliefs, or confidence in treating suicidal clients. J. Subst. Abus. Treat. 2019, 106, 29-34. [CrossRef] [PubMed]

153. Lynch, F.L.; Peterson, E.L.; Lu, C.Y.; Hu, Y.; Rossom, R.C.; Waitzfelder, B.E.; Owen-Smith, A.A.; Hubley, S.; Prabhakar, D.; Williams, L.K.; et al. Substance use disorders and risk of suicide in a general US population: A case control study. Addict. Sci. Clin. Pr. 2020, 15, 14. [CrossRef] 
154. Zhornitsky, S.; Le, T.M.; Dhingra, I.; Adkinson, B.D.; Potvin, S.; Li, C.R. Interpersonal risk factors for suicide in cocaine dependence: Association with self-esteem, personality traits, and childhood abuse. Suicide Life-Threat. Behav. 2020, 50, 867-883. [CrossRef]

155. Miller, N.S.; Mahler, J.C.; Gold, M.S. Suicide risk associated with drug and alcohol dependence. J. Addict. Dis. 1991, $10,49-61$. [CrossRef]

156. Arensman, E.; Bennardi, M.; Larkin, C.; Wall, A.; McAuliffe, C.; McCarthy, J.; Williamson, E.; Perry, I. Suicide among young people and adults in Ireland: Method characteristics, toxicological analysis and substance abuse histories compared. PLoS ONE 2016, 11, e0166881. [CrossRef] [PubMed]

157. Masferrer, L.; Caparrós, B. Risk of suicide and dysfunctional patterns of personality among bereaved substance users. Int. J. Environ. Res. Public Health 2017, 14, 316. [CrossRef] [PubMed]

158. Lasota, D.; Al-Wathinani, A.; Krajewski, P.; Mirowska-Guzel, D.; Goniewicz, K.; Hertelendy, A.J.; Alhazmi, R.A.; Pawłowski, W.; Khorram-Manesh, A.; Goniewicz, M. Alcohol and the risk of railway suicide. Int. J. Environ. Res. Public Health 2020, 17, 7003. [CrossRef] [PubMed]

159. Pirkola, S.P.; Suominen, K.; Isometsä, E.T. Suicide in alcohol-dependent individuals: Epidemiology and management. CNS Drugs. 2004, 18, 423-436. [CrossRef]

160. Borges, G.; Bagge, C.L.; Orozco, R. A literature review and meta-analyses of cannabis use and suicidality. J. Affect. Disord. 2016, 195, 63-74. [CrossRef]

161. Han, B.; Compton, W.M.; Einstein, E.B.; Volkow, N.D. Associations of suicidality trends with cannabis use as a function of sex and depression status. JAMA Netw. Open 2021, 4, e2113025. [CrossRef] [PubMed] 